\title{
Purified Anthocyanin, its Elicitation from Cell Cultures of Begonia malabarica and Begonia rex-cultorum 'Baby Rainbow'and its In vitro Cytotoxicity Analysis by MTT Assay
}

\author{
Aswathy Jayasree Madanakumar, Murugan Kumaraswamy*
}

\section{Aswathy Jayasree Madanakumar, Murugan Kumaraswamy*}

Plant Biochemistry and Molecular Biology Laboratory, Department of Botany, University College, Trivandrum, 695 034, Kerala, INDIA.

\section{Correspondence}

\section{Murugan Kumaraswamy}

Plant Biochemistry and Molecular Biology Laboratory, Department of Botany, University College, Trivandrum, 695 034, Kerala, INDIA.

Phone no : 9447077895

E-mail: harimurukan@gmail.com

\section{History}

- Submission Date: 29-12-2017

- Review completed: 05-03-2018;

- Accepted Date: 05-03-2018

DOI : 10.5530/pj.2018.3.90

Article Available online http://www.phcogj.com/v10/i3

\section{Copyright}

(C) 2018 Phcog.Net. This is an openaccess article distributed under the terms of the Creative Commons Attribution 4.0 International license.

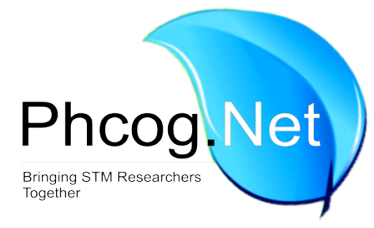

\begin{abstract}
Background: According to recent statistics, cancer accounts about marked percentage of total deaths in the world, although there are many therapeutic approaches. Unfortunately, the cytotoxicity properties of most chemotherapy drug are nonspecific and therefore do not distinguish between normal healthy cells and tumor cells, these events have led to inappropriate and toxic therapeutic agents with a wide range of side effects. However, several experimental and epidemiological studies have suggested that fruits and vegetables are associated with low risk of various types of cancer. Anthocyanins are natural pigments that provide intense purple to red color in plants. Anthocyanin possess the ability to inhibit oxidative stress and to induce apoptosis in malignant cells, thus may prevent carcinogenesis. Methods: Antiproliferative properties of purified anthocyanin extract from elicited cell suspension cultures of Begonia malabarica and Begonia rex-cultorum 'Baby rainbow' was investigated in terms of MTT assay. Anthocyanin extracts were tested for their ability to inhibit the growth of HT29 (colon cancer cells), MG63 (Osteosarcoma), HeLa (Cervical cancer cells) and L929 (Mouse Fibroblast L929) cell lines. Results: Cell viability decreased in a dose dependent manner in all the considered cell lines treated with anthocyanin extracts. The extract of Begonia rex-cultorum 'Baby rainbow' exhibited significant cytotoxic activity against all tumor cell lines than Begonia malabarica extract. Begonia malabarica and Begonia rex-cultorum 'Baby rainbow' anthocyanin extract exhibited the highest cytotoxicity towards HT29 and HeLa cell lines respectively. But, MG63 resulted in comparatively higher percentage of viability of cell lines at the same concentrations. The anthocyanin extract produced significant morphological alterations on cell lines in culture. Meanwhile, the extracts showed poor cytotoxicity against the normal cell line. Conclusion: The morphological alteration of the treated cancer cells presented clear evidence of significant cytotoxicity of anthocyanin extracts of both Begonias in all the three cell lines. Thus, anthocyanin may act as chemopreventive agents for various cancer cell lines.

Key words: Cytotoxicity, Cancer, Begonia, MTT assay, Anthocyanin, Cell suspension.
\end{abstract}

\section{INTRODUCTION}

Cancers present a serious life style disorder and pose significant social and economic impacts on the health care system. Although there has been considerable improvement in the treatment of cancer, the overall prognosis remains unsatisfied. ${ }^{1}$ More than $40 \%$ of the drugs identified were natural products and have not been chemically synthesized. Natural products and their derivatives including vinblastine, paclitaxel, and etoposide already proved critical roles in cancer chemotherapy. Anthocyanins are versatile group of polyphenolic compounds identified in plants responsible for vivid blue, purple, and red colour of fruits, vegetables and flowers. ${ }^{2}$ Currently, anthocyanins have received much attention as a natural source of food and textile colourants. There is an increasing demand for natural food colourants that can be used as substitutes for synthetic colours. Moreover, anthocyanins possess putative health benefits as dietary antioxidants. The roles of anthocyanin as medicinal agents have been well-accepted dogma in folk therapy throughout the world. Secondary metabolites with bioactivity were isolated and used either directly or after chemical modification. Their pharmacological values are increasing due to the constant discoveries of their potential role in healthcare and as lead molecule for new drug designing. Begonia, a perennial flowering plant belongs to the family Begoniaceae, are rich source of anthocyanin content. Synthesis of anthocyanins often requires elicitors, which act as molecular signals in plant stress responses. Elicitation of cell cultures (using chemical or environmental) is a recognized and efficient means of maximizing anthocyanin pigment towards commercialization of product recovery. In both in vitro and in vivo research trials have demonstrated that the marked ability of anthocyanin to reduce malignant cell proliferation and to inhibit tumor formation. ${ }^{3}$
Cite this article: Madanakumar AJ, Kumaraswamy M. Purified Anthocyanin, its Elicitation from Cell Cultures of Begonia malabarica and Begonia rex - cultorum 'Baby Rainbow'and it's In vitro Cytotoxicity Analysis by MTT Assay. Pharmacog J. 2018;10(3):553-8 
Phytochemicals capable of retarding the cell cycle and/or activating the cellular apoptotic response in the cancerous cells is an attractive trend in antimetastatic studies. Thus, in the present study, a comparison of preliminary antiproliferative potential of the purified anthocyanin from the cell suspension cultures of Begonia malabarica and Begonia rex cultorum 'Baby rainbow' were carried out on selected cell lines.

\section{MATERIALS AND METHODS}

\section{Plant materials}

The fresh healthy plants of Begonia malabarica and B. rex-cultorum 'Baby rainbow' were collected from the wild habitats. Identity was confirmed by referring floras and authenticated with herbaria of Jawaharlal Nehru Tropical Botanical Garden and Research Institute, Palode, Kerala. The voucher specimen was deposited in the herbarium of University College, Trivandrum (UCB 1207, UCB 1208)

\section{Establishment of cell suspension culture}

Fresh callus of Begonias species was cultured in a $250 \mathrm{~mL}$ flask with $40 \mathrm{~mL}$ of modified liquid MS culture medium at $(25 \pm 1)^{\circ} \mathrm{C}$ on a rotary shaker with a speed of 100 rotations per min (rpm) under $16 \mathrm{~h}$ illumination with $80 \mu \mathrm{mol} \mathrm{m}{ }^{-2} \mathrm{~s}^{-1}$. The medium was autoclaved at $121^{\circ} \mathrm{C}$ for $20 \mathrm{~min}$.

The cell suspension derived from the $1 \mathrm{~g}$ calli tissue from leaf explants of B. malabarica were subcultured in liquid MS culture medium containing 2,4-D (0.1 mg L $\left.\mathrm{mg}^{-1}\right)$, NAA $\left(0.5 \mathrm{mg} \mathrm{L}^{-1}\right)$, and BAP $\left(0.5 \mathrm{mg} \mathrm{L}^{-1}\right)$ every week until the cells showed continuous and stable accumulation of biomass. Meanwhile, in B. rex-cultorum 'Baby rainbow' (leaf explant) cell suspension was established in liquid MS medium supplemented with the growth regulators such as BAP $\left(1 \mathrm{mg} \mathrm{L}^{-1}\right)+2,4-\mathrm{D}\left(0.5 \mathrm{mg} \mathrm{L}^{-1}\right)$, BAP $\left(2.0 \mathrm{mg} \mathrm{L}^{-1}\right)$ + IAA (1.0 mg L $\left.\mathrm{m}^{-1}\right), \mathrm{KN}\left(2 \mathrm{mg} \mathrm{L}^{-1}\right)+\mathrm{IAA}\left(1 \mathrm{mg} \mathrm{L}^{-1}\right)$ and $\mathrm{KN}\left(2 \mathrm{mg} \mathrm{L}^{-1}\right)$ $+2,4-\mathrm{D}\left(1 \mathrm{mg} \mathrm{L}^{-1}\right)$.

After cell culture for one cycle, the cells were harvested by filtration via a Buchner funnel, washed with distilled water to remove residual medium, and filtered again. Then, the weighed fresh cells (FW) were dried at $50^{\circ} \mathrm{C}$ to constant dry weight (DW). Cell growth was measured based on the FW and DW. Every 20 days, cells were subcultured to fresh media [with $5.0 \mathrm{~g}$ fresh weight $(\mathrm{FW})]$ in $250-\mathrm{mL}$ flasks.

\section{Elicitation of anthocyanin in cell suspension culture}

Different concentrations of peptone water, yeast extracts, phenylalanine, abscisic acid (ABA), salicylic acid (SA), zinc sulphate and methyl jasmonate (MeJA) were used to study the elicitation effect on anthocyanin production on the cell suspension cultures of B.malabarica (BM) and $B$. rex-cultorum 'Baby rainbow' (BR). MeJA and SA were dissolved in ethanol and all others were dissolved in water and were filtered before adding into the suspension cultures. Based on the results of preliminary experiments, the concentration employed were peptone water $(0.015 \%)$, yeast extracts $(1 \%)$, phenylalanine $(10 \mu \mathrm{M})$, abscisic acid $(0.25 \mathrm{mg} / \mathrm{L})$, salicylic acid $(60 \mu \mathrm{M})$, zinc sulphate $(50 \mu \mathrm{M}))$ and methyl jasmonate $(1 \mu \mathrm{M})$. All experiments were performed in triplicate.

\section{Quantification and purification of anthocyanin}

Anthocyanin was isolated and quantified from the in vitro cell suspension and in vivo plants. The anthocyanin elicited cell suspension culture and fresh leaves were homogenized in $3 \mathrm{ml}$ methanol with $1 \% \mathrm{HCl}$ and the extract was used for quantification of anthocyanin by the protocol of Sutharut and Sudarat. ${ }^{4}$ The absorbance was read at 510 and $700 \mathrm{~nm}$ against distilled water as blank.

The combined aqueous concentrates of anthocyanin after evaporation were purified by partition method against ethyl acetate and further purified by Amberlite XAD-7 column chromatography. Then, the adsorbed anthocyanins were eluted using ethanol containing $7 \%$ acetic acid (v/v) as mobile phase.
The column eluted fraction with highest anthocyanin content was used for the LC-MS analysis. The experiment was performed on a Thermo Scientific Dionex UltiMate 3000 RSLC system with chromatographic separation achieved on a Thermo Scientific Acclaim ${ }^{\circledR}$ RSLC 120 C18 reversed-phase column $(2.1 \times 100 \mathrm{~mm}, 2.2 \mu \mathrm{m})$ operated at $40^{\circ} \mathrm{C}$ with gradient elution at $0.5 \mathrm{~mL} / \mathrm{min}$. The mobile phase consisted of three components: A) acetonitrile, B) deionized (DI) water, and C) $20 \%$ formic acid. Mobile phase $C$ was held constant at $10 \%$ to provide $2 \%$ total formic acid in the mobile phase throughout the run. Mobile phase A was ramped from $0 \%$ to $8 \%$ from 11 to $42 \mathrm{~min}$, then held for $13 \mathrm{~min}$ before returning to the initial composition from 55 to $60 \mathrm{~min}$. Electrospray ionization (ESI) was used as the interface and was operated in positive selected ion monitoring (SIM) mode. The probe temperature was set at $500^{\circ} \mathrm{C}$ and needle voltage was set at $2000 \mathrm{~V}$. The cone voltage was set at $50 \mathrm{~V}$ for all SIM scans with a span of $0.3 \mathrm{amu}$ for each SIM.

\section{In vitro antiproliferative effect determination by MTT assay}

HT29 (colon cancer cells), MG63 (Osteosarcoma), HeLa (Cervical cancer cells) and L929 (Mouse Fibroblast L929) cell lines were cultured in $25 \mathrm{~cm}^{2}$ DMEM supplemented with 10\% FBS, L-glutamine, sodium bicarbonate and antibiotic solution containing: Penicillin $\left(100 \mathrm{U} \mathrm{ml}^{-1}\right)$, Streptomycin $\left(100 \mu \mathrm{g} \mathrm{ml}^{-1}\right)$, and Amphoteracin B $\left(2.5 \mu \mathrm{g} \mathrm{ml}^{-1}\right)$. Cultured cell lines were kept at $37^{\circ} \mathrm{C}$ in a humidified $5 \% \mathrm{CO}_{2}$ incubator. The viability of cells was evaluated by direct observation of cells by Inverted phase contrast microscope and followed by MTT assay method. Two days old confluent monolayers of cells were trypsinized and the cells were suspended in $10 \%$ growth medium. $100 \mu \mathrm{l}$ cell suspension $\left(5 \times 10^{4}\right.$ cells/ well) was seeded in 96 well tissue culture plates and incubated at $37^{\circ} \mathrm{C}$ in a humidified 5\% CO2 incubator. After $24 \mathrm{~h}$ the growth medium was removed, freshly prepared anthocyanin extracts in 5\% DMEM were five times serially diluted by two-fold dilution $(100,50,25,12.5,6.25 \mu \mathrm{g}$ in $1000 \mu \mathrm{l}$ of 5\% MEM) and each concentration of $100 \mu \mathrm{l}$ were added in triplicates to the respective wells and incubated at $37^{\circ} \mathrm{C}$ in a humidified $5 \% \mathrm{CO}_{2}$ incubator.

Detectable changes in the morphology of the cells, such as rounding or shrinking of cells, granulation and vacuolization in the cytoplasm of the cells were considered as indicators of cytotoxicity. $15 \mathrm{mg}$ of MTT was reconstituted in $3 \mathrm{ml}$ PBS until completely dissolved and sterilized by filter sterilization. MTT assay was carried as per the protocol of Laura et al. ${ }^{5}$ The absorbance was measured by using microplate reader at $570 \mathrm{~nm}$. The percentage of growth inhibition was calculated using the formula:

$$
\% \text { of viability }=\frac{\text { Mean OD Samples } \times 100}{\text { Mean OD of control group }}
$$

\section{Statistical analysis}

Analysis of variance (ANOVA) was used to determine significant differences between treatments, using the statistical package STATISTICA. All the values were mean of 12 replicates \pm SE. Significance level was noticed $5 \%$.

\section{RESULTS AND DISCUSSION}

\section{Cell suspension culture of B. malabarica and B. rex-cultorum 'Baby} rainbow'

Cell suspension culture was established by culturing fresh friable calli from the leaf explants of $B$. malabarica in liquid MS media supplemented with definite combinations and doses of BAP, 2, 4-D and NAA with concentrations $0.5,0.1,0.5 \mathrm{mg} \mathrm{L}^{-1}$ respectively. MS liquid medium supplemented with 2, 4-D (0.1 $\left.\mathrm{mg} \mathrm{L}^{-1}\right)$ and BAP $\left(0.5 \mathrm{mg} \mathrm{L}^{-1}\right)$ combinations showed well established suspension cultures i.e., suspensions without any aggregation or clumps of cells (Figure 1a). The in vitro suspension of 

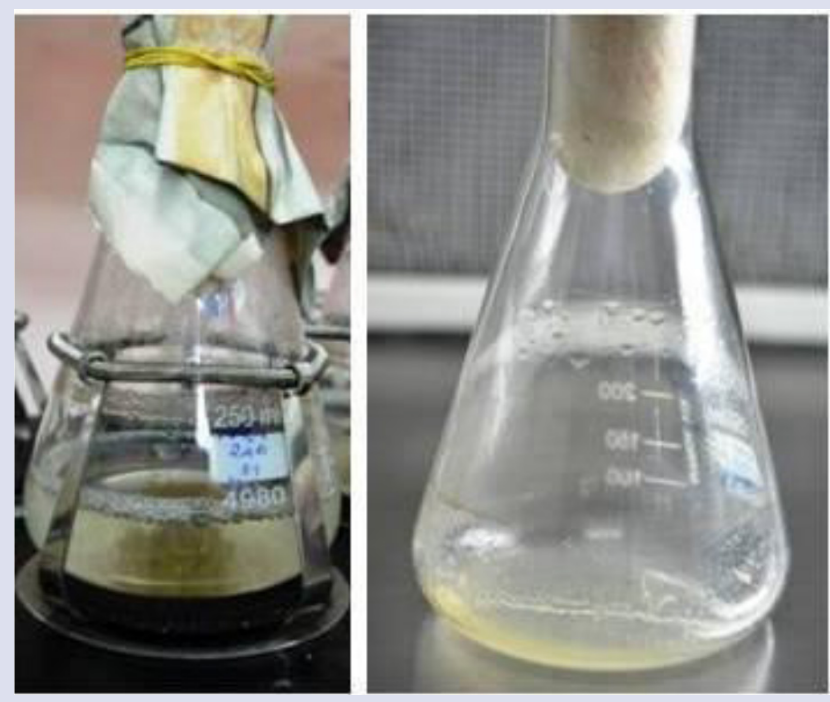

Figure $1 \mathrm{~A}$ : Cell suspension culture of Begonia malabarica from friable callus in MS medium fortified with 2, 4-D (0.1 mg L-1) and BAP (0.5 mg L-1) Figure $1 \mathrm{~b}$ : Cell suspension culture of Begonia rex - cultorum 'Baby rainbow' from friable callus in MS medium fortified with $2,4-\mathrm{D}(0.5 \mathrm{mg}$ $\mathrm{L}-1)$ and BAP (1.0 mg L-1).

cells from B. malabarica revealed optimal and steady biomass accumulation on day 14. The same medium and growth hormone combinations were used for further growth kinetics studies. After $16^{\text {th }}$ day, cells in the suspension exhibited a reduction in fresh weight as well as dry weight of cells (Table 1$)$. The maximum fresh weight $(8.0 \mathrm{~g})$ and dry weight $(0.83 \mathrm{~g})$ was noticed at $14^{\text {th }}$ day of culture in liquid MS medium complimented with 2, 4-D $\left(0.1 \mathrm{mg} \mathrm{L}^{-1}\right)+\operatorname{BAP}\left(0.5 \mathrm{mg} \mathrm{L}^{-1}\right)$. The time course of biomass accumulation was the typical sigmoid growth curves.

Similarly, the cell suspension culture was evaluated by culturing calli of B.malabarica in the liquid MS medium fortified with the combinations of $\operatorname{BAP}(0.5,1,1.5)$ and NAA $\left(0.1,0.5,1.0 \mathrm{mg} \mathrm{L}^{-1}\right)$. MS liquid medium supplemented with NAA and BAP showed less significant suspension cultures with aggregated or clumped cells. Generally, the cell growth was slow during the initial 5 days of culturing. Thereafter, biomass accumulated rapidly, and reached the highest value on the $14^{\text {th }}$ day. Then the culture entered the stationary phase and declined marginally. Some cultures continued to grow even up to $30^{\text {th }}$ day.

Suspension cultures were also initiated for B. rex-cultorum 'Baby rainbow' with $2 \mathrm{~g}$ of friable callus as an inoculum in the liquid MS medium supplemented with the different combinations of the growth regulators ie., BAP $\left(1 \mathrm{mg} \mathrm{L}^{-1}\right)+2,4$-D $\left(0.5 \mathrm{mg} \mathrm{L}^{-1}\right)$, BAP $\left(2.0 \mathrm{mg} \mathrm{L}^{-1}\right)+$ IAA (1.0 $\left.\mathrm{mg} \mathrm{L}^{-1}\right), \mathrm{KN}\left(2 \mathrm{mg} \mathrm{L}^{-1}\right)+\mathrm{IAA}\left(1 \mathrm{mg} \mathrm{L}^{-1}\right)$ and $\mathrm{KN}\left(2 \mathrm{mg} \mathrm{L}^{-1}\right)+2,4-\mathrm{D}$ $\left(1 \mathrm{mg} \mathrm{L}^{-1}\right)$. Maximum growth was achieved in suspension culture supplemented with BAP $\left(1 \mathrm{mg} \mathrm{L}^{-1}\right)+2,4-\mathrm{D}\left(0.5 \mathrm{mg} \mathrm{L}^{-1}\right)$, followed by KN $(2 \mathrm{mg}$ $\left.\mathrm{L}^{-1}\right)+$ IAA $\left(1 \mathrm{mg} \mathrm{L}^{-1}\right)$. BAP $\left(2.0 \mathrm{mg} \mathrm{L}^{-1}\right)+\mathrm{IAA}\left(1.0 \mathrm{mg} \mathrm{L}^{-1}\right), \mathrm{KN}\left(2 \mathrm{mg} \mathrm{L}^{-1}\right)$ +2 ,4-D $\left(1 \mathrm{mg} \mathrm{L}^{-1}\right)$ combinations showed only minimum outputs. The maximum fresh weight $(7.37 \mathrm{~g})$ and dry weight $(0.70 \mathrm{~g})$ was observed at $14^{\text {th }}$ day of culture in liquid MS medium supplemented with $2,4-\mathrm{D}(0.5$ $\left.\mathrm{mg} \mathrm{L}^{-1}\right)$ and BAP $\left(1 \mathrm{mg} \mathrm{L}^{-1}\right)$. Here also, the cell suspension growth was sigmoidal (Figure $1 \mathrm{~b}$, Table 2).

\section{Quantification of anthocyanin}

Anthocyanin was quantified from the in vitro cell suspension culture and in vivo plants. The in vitro cells showed remarkable level of anthocyanin ie., $10.4 \mathrm{mg}$ and $20.6 \mathrm{mg} / 100 \mathrm{ml}$ for Begonia malabarica and
B. rex-cultorum 'Baby rainbow' respectively. However, in the in vivo plants anthocyanin content noticed was $5.7 \mathrm{mg} \mathrm{g}^{-1}$ for Begonia malabarica and for B. rex-cultorum 'Baby rainbow' $9.8 \mathrm{mg} \mathrm{g}^{-1}$. From the given results it can be speculated that anthocyanin content may be effectively induced through in vitro culture by changing the culture parameters. The present results seem to be more effective and supported by other in vitro cultures of phytochemicals from medicinal plants.

\section{Elicitation by chemicals on anthocyanin production}

B. malabarica and B. rex-cultorum 'Baby rainbow' cell suspension cultures showed poor accumulation of anthocyanin under elicitation using peptone water and yeast extracts. Similarly, the addition of phenylalanine $(10 \mu \mathrm{M})$, the precursor of secondary metabolite synthesis at lower doses enhanced the anthocyanin synthesis in the cells. In fact, abscisic acid (ABA) $(0.25 \mathrm{mg} / \mathrm{L})[18.6 \mathrm{~g} / 100 \mathrm{~mL}$ (B. malabarica) and $30.8 \mathrm{~g} / 100 \mathrm{~mL}$ (B. rex-cultorum 'Baby rainbow')] and salicylic acid (SA) $(60 \mu \mathrm{M})$ [19.2 g/100 mL (B. malabarica) and $34.4 \mathrm{~g} / 100 \mathrm{~mL}$ (B. rex-cultorum 'Baby rainbow')] elicited anthocyanin synthesis remarkably with anthocyanin content (i.e., promising effect on anthocyanin induction in cell suspension cultures). Zinc sulphate at lower dose showed slight rise in anthocyanin production $(50 \mu \mathrm{M})$, but the content was lower than that of SA or ABA treatments. MeJ did not showed remarkable increase in anthocyanin production in cell cultures. Meanwhile, Saniewski et al. ${ }^{6}$ succeeded in inducing anthocyanin synthesis by methyl jasmonate in shoots of Crassula multicava. Cetin and Baydar ${ }^{7}$ elicited effectively cell suspension culture of phenolic compound synthesis in grapevine using physical parameters.

\section{Purification and identification of anthocyanin}

$25 \mathrm{~g}$ of fresh, homogenized cell suspension sample was extracted out from the cultures of Begonia malabarica and B. rex-cultorum 'Baby rainbow'. The combined aqueous concentrates after evaporation were purified by partition method against ethyl acetate to remove chlorophylls, stilbenoids, less polar flavonoids and other non-polar compounds from the mixture. The non-aromatic compounds were removed with the use of Amberlite XAD-7 column chromatography. Amberlite XAD-7 adsorbs the aromatic compounds including anthocyanins and other flavonoids in aqueous solutions, whereas free sugars and other polar non-aromatic compounds were removed by washing with distilled water until the eluted water has a neutral $\mathrm{pH}$. Therefore, aqueous acidified ethanol with the concentration of $75 \%$ was used for the desorption of anthocyanins from the Amberlite XAD-7HP column. Subsequently, purified amberlite column eluted fraction was used for the antimetastatic analysis.

LC- MS/MS was successful in identifying the major anthocyanin fractions of B. malabarica and B. rex-cultorum 'Baby rainbow'. The major anthocyanin fractions from the two species were eluted between 4.7 and $5.4 \mathrm{~min}$. Tandem MS of the $\mathrm{m} / z 655.3$ peak was identified as the major anthocyanidin fraction namely, malvidin-3,5-diglucoside. The other peaks identified were malvidin or peonidin (584.3), delphinidin + glucose (459.2), cyanidin (403.2) and cyanidin aglycone (287.1). The others were sugar derivatives or minor fragments $(\mathrm{m} / \mathrm{z} 242.3,195.1$ and 144.1) (Figure 2 a). Meanwhile, the major anthocyanin of B. rex-cultorum 'Baby rainbow' were similar to the anthocyanins of B.malabarica and were identified as (655.3) malvidin-3 -diglucoside, (584.3) malvidin or peonidin, (468.4) delphinidin + glucose, (403.2) cyanidin, (286.2) cyanidin aglycone and others $(242.3,195.1$ and 144.1) may be sugar derivatives or insignificant fragments (Figure $2 \mathrm{~b}$ ).

\section{Cytotoxicity analysis by MTT assay}

Many vegetables and fruits in the human diet have been proved as potential neutraceutical agents and consuming optimal amounts can inhibit the development of life style diseases. Cancer is one of the major issues 


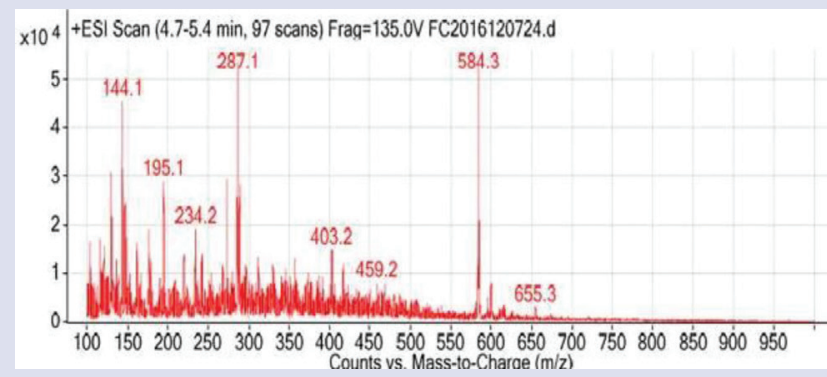

Figure 2 a: LC- MS analysis of B. malabarica.

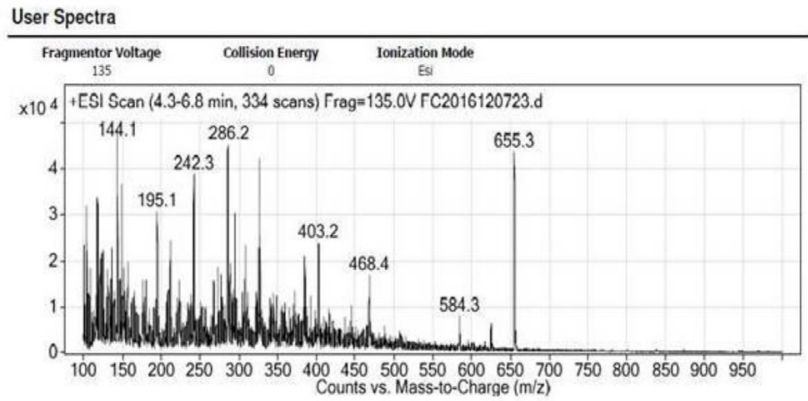

Figure 2 b: LC- MS analysis of B. rex-cultorum 'Baby rainbow'.

Table 1: Fresh (FW) as well as dry weight (DW) of cells obtained in suspension culture for first 20 days of B.malabarica in liquid MS medium with 2, 4-D $\left(0.1 \mathrm{mg} \mathrm{L}^{-1}\right)+$ BAP $\left(0.5 \mathrm{mg} \mathrm{L}^{-1}\right)$.

\begin{tabular}{|c|c|c|}
\hline Days & FW -Mean (g) & DW-Mean (g) \\
\hline 2 & 0.844 & 0.130 \\
\hline 4 & 2.268 & 0.366 \\
\hline 6 & 3.454 & 0.418 \\
\hline 8 & 5.388 & 0.504 \\
\hline 10 & 6.108 & 0.628 \\
\hline 12 & 7.106 & 0.738 \\
\hline 14 & 8.090 & 0.832 \\
\hline 16 & 8.082 & 0.848 \\
\hline 18 & 7.834 & 0.836 \\
\hline 20 & 7.800 & 0.820 \\
\hline Mean & 5.697 & 0.612 \\
\hline F- FW & \multicolumn{2}{|c|}{1735.196} \\
\hline F-DW & \multicolumn{2}{|c|}{196.730} \\
\hline SE-FW & \multicolumn{2}{|c|}{1.51} \\
\hline SE-DW & \multicolumn{2}{|c|}{5.57} \\
\hline CD-FW & \multicolumn{2}{|c|}{4.953} \\
\hline CD-DW & \multicolumn{2}{|c|}{1.817} \\
\hline
\end{tabular}

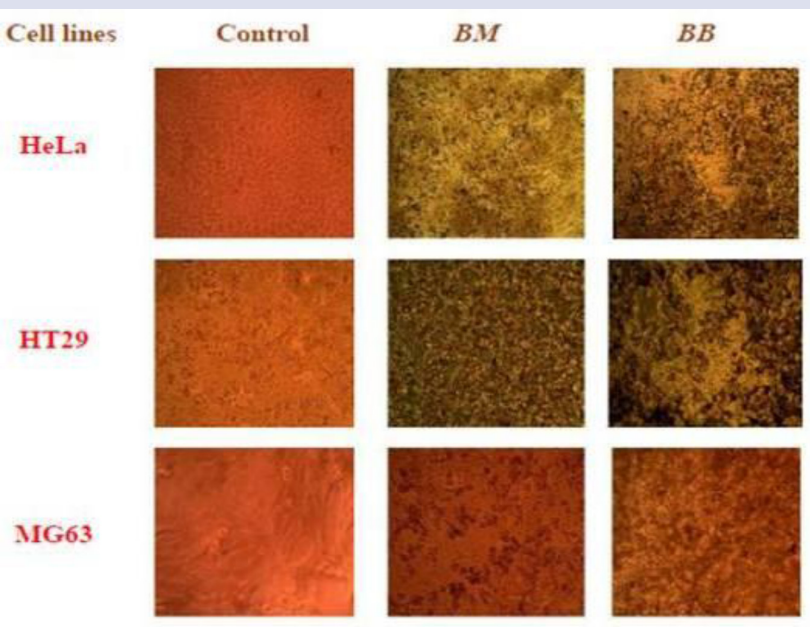

Figure 3: MTT assay of purified anthocyanin extract of Begonia malabarica and B. rex-cultorum 'Baby rainbow' on different cell lines (100 $\mu \mathrm{g} \mathrm{ml-1}$ concentration) along with their control.

Table 2: Fresh (FW) as well as dry weight (DW) of cells obtained in suspension culture for first 20 days B.rex-cultorum 'Baby rainbow' in liquid MS medium BAP $\left(1 \mathrm{mg} \mathrm{L}^{-1}\right)+2,4-D\left(0.5 \mathrm{mg} \mathrm{L}^{-1}\right)$.

\begin{tabular}{cccc}
\hline Days & Mean & Mean \\
\hline 2 & 0.740 & 0.136 \\
4 & 1.814 & 0.366 \\
6 & 2.598 & 0.4400 \\
8 & 3.152 & 0.476 \\
10 & 4.364 & 0.538 \\
12 & 5.876 & 0.556 \\
14 & 7.378 & & 0.704 \\
16 & 7.382 & & 0.704 \\
18 & 7.378 & & 0.698 \\
20 & 7.344 & & 0.694 \\
Mean & 4.803 & & 0.531 \\
F-FW & & 1563.58 & \\
F-DW & & 196.730 & \\
SE-FW & & 6.57 & \\
SE-DW & & 1.54 & \\
CD-FW & & 0.185 & \\
CD-DW & & 4.353 & \\
\hline
\end{tabular}

worldwide. Therapeutic herbals have been utilized massively by the local populations as remedial for many disorders and hence, it is need of the hour to evaluate the efficacy in terms of toxicity in using them. Several studies have reported that herbal extracts can be used in the management of oxidative stress.

In vitro cytotoxicity activity analysis against selected cancer cell lines

In the present study, the cytotoxic effect of purified anthocyanin was analyzed using MTT assay on three cancer cell lines (HT29, MG63 and HeLa cell lines) and one normal cell line (Mouse Fibroblast L929). The concentration employed ranged from 6.25 to $50 \mu \mathrm{g} \mathrm{ml}^{-1}$. IC $\mathrm{I}_{50}$ level of 
Table 3a: Percentage of viability of different cancer cell lines against purified anthocyanin from Begonia malabarica.

\begin{tabular}{cccc}
\hline $\begin{array}{c}\text { Concentration }\left(\mu \mathrm{g} \mathrm{ml}^{-1}\right) \\
\text { HELA Cervical }\end{array}$ & $24 \mathrm{~h}$ & $48 \mathrm{~h}$ & $72 \mathrm{~h}$ \\
\hline 6.25 & 88.15 & 70.2 & 61.5 \\
12.5 & 65.48 & 59.3 & 53.6 \\
25 & 52.02 & 47.4 & 41.7 \\
50 & 31.38 & 29.5 & 28.2 \\
HT29 Colon & & & \\
6.25 & 75.42 & 69.3 & 63.5 \\
12.5 & 61.18 & 55.2 & 54.0 \\
25 & 50.21 & 47.0 & 45.2 \\
50 & 38.4 & 34.3 & 33.0 \\
MG63 Bone & & & \\
6.25 & 82.38 & 74.4 & 61.0 \\
12.5 & 70.62 & 63.2 & 54.5 \\
25 & 60.08 & 53.0 & 43.0 \\
50 & 51.8 & 47.3 & 30.1 \\
F HELA & $3254.69^{* *}$ & $2815.2^{* *}$ & $2459.6^{* *}$ \\
F HT29 & $1398.44^{* *}$ & $1416.5^{* *}$ & $1512.4^{* *}$ \\
FMG63 & $1668.28^{* *}$ & $1715.3^{* *}$ & $1800.6^{* *}$ \\
CD & 0.410 & 0.312 & 0.504 \\
\hline
\end{tabular}

anthocyanin was further evaluated at different time intervals i.e., 24, 48 and $72 \mathrm{~h}$ against each cell lines. The in vitro cytotoxic activities of purified anthocyanin from Begonia malabarica and B. rex-cultorum 'Baby rainbow' were shown in the Table $3 \mathrm{a}$ and $\mathrm{b}$ and $\mathrm{IC}_{50}$ values were determined from the dose response curves (Table $3 \mathrm{a}$ and $\mathrm{b}$ ). Comparison of purified anthocyanins from the two-species revealed that anthocyanin from B. rex-cultorum 'Baby rainbow' exhibited significant cytotoxic activity against all tumor cell lines with remarkable $\mathrm{IC}_{50}$ values. However, anthocyanin of B. malabarica showed tumor selective cytotoxic activity depending on the cell line type i.e., HeLa cervical cell were the most sensitive cell line and MG63 was the most resistant tumor cell line (in terms of $\mathrm{IC}_{50}$ values). Meanwhile, $B$. rex-cultorum 'Baby rainbow' anthocyanin extract was more cytotoxic against HT29 cell lines followed by MG63 bone cells (Table $3 \mathrm{a}$ and $\mathrm{b}$ ). The values obtained were statistically significant.

The cytotoxic impact of the anthocyanin was evaluated via MTT assay revealed the cell viability based on the reduction of yellow tetrazolium MTT to a purple formazan dye by the mitochondrial dehydrogenase enzyme. The quantity of formazan produced reflects indirectly the number of metabolically active viable cells. MTT results showed that anthocyanin of both the species displayed cytotoxic effect against cancer cell lines in a concentration dependent manner. Such anti-proliferative potential of anthocyanin was featured by its concentration and tumorselective manner, as reflected by the comparatively low $\mathrm{IC}_{50}$ values. The $\mathrm{IC}_{50}$ concentrations of anthocyanin from B. malabarica and B. rex-cultorum 'Baby rainbow' were evaluated against different cell line for $24 \mathrm{~h}$. The $\mathrm{IC}_{50}$ values of B. malabarica were 35.9, 26.2, $53.2 \mu \mathrm{g} \mathrm{mL}^{-1}$ against HeLa, HT 29, MG63 cell lines respectively. Meanwhile, $B$. rex-cultorum 'Baby rainbow' displayed 38.7, 20.4, $26.83 \mu \mathrm{g} \mathrm{mL}^{-1}$ against HeLa, HT 29, MG63 cell lines respectively. Anthocyanin extracts of $B$. malabarica and B. rex-cultorum 'Baby rainbow' have shown significant inhibition of HT29 cell proliferation as compared to other cell lines. Further, a duration $(24,48,72 \mathrm{~h})$ and concentration dependent analysis was carried. When the duration of
Table 3b: Percentage of viability of different cancer cell lines against purified anthocyanin from Begonia rex-cultorum 'Baby rainbow'.

\begin{tabular}{|c|c|c|c|}
\hline CONCENTRATION $\left(\mu \mathrm{g} \mathrm{ml}^{-1}\right)$ & $24 \mathrm{~h}$ & $48 \mathrm{~h}$ & $72 \mathrm{~h}$ \\
\hline \multicolumn{4}{|l|}{ HELA Cervical } \\
\hline 6.25 & 73.5 & 70.2 & 62.6 \\
\hline 12.5 & 65.12 & 61.5 & 53.8 \\
\hline 25 & 53.15 & 50.2 & 44.3 \\
\hline 50 & 40.88 & 37.3 & 30.2 \\
\hline \multicolumn{4}{|l|}{ HT29 Colon } \\
\hline 6.25 & 67.68 & 60.7 & 51.3 \\
\hline 12.5 & 57.65 & 49.3 & 41.6 \\
\hline 25 & 38.3 & 31.2 & 27.5 \\
\hline 50 & 26.62 & 24.3 & 19.6 \\
\hline \multicolumn{4}{|l|}{ MG63 Bone } \\
\hline 6.25 & 71.86 & 64.5 & 55.2 \\
\hline 12.5 & 69.32 & 54.2 & 44.4 \\
\hline 25 & 50.32 & 37.6 & 30.3 \\
\hline 50 & 39.18 & 30.1 & 22.5 \\
\hline F HELA & $1157.02^{* *}$ & $1816.5^{* *}$ & $1714.63^{* *}$ \\
\hline F HT29 & $1967.18^{* *}$ & $1188.5^{* *}$ & $1316.54^{* *}$ \\
\hline FMG63 & $1775.14^{* *}$ & $1610.61^{* *}$ & $1488.59 * *$ \\
\hline$C D$ & 0.421 & 0.358 & 0.324 \\
\hline
\end{tabular}

treatment was prolonged to 48 and $72 \mathrm{~h}$, the \% of viability was found to decrease concentration and duration dependently. At the concentrations of $6.25,12.5,25$ and $50 \mu \mathrm{g} \mathrm{mL}{ }^{-1}$ of B. malabarica, the $\%$ of viability further decreased to $61.5,53.6,41.7,28.2 \%$ respectively in HeLa cells after 72h. A similar tendency was noticed with HT29 and MG63 cell lines. The results were found to be statistically significant. The concentration and duration dependency of anthocyanin extract may be due to the presence of different anthocyanin fractions that function synergistically together. B. rex-cultorum 'Baby rainbow' also showed a similar trend against HeLa, HT29 and MG63 cell lines (Table $3 \mathrm{a}$ and b)

\section{Cytotoxic effect on Mouse Fibroblast (L929) Cells}

No significant cytotoxicity was noticed with the anthocyanin of $B$. malabarica and $B$. rex-cultorum 'Baby rainbow' by MTT assay on mouse fibroblast (L929) cells. The $\mathrm{IC}_{50}$ values were found to be 14.8 and $5.5 \mathrm{~g} \mathrm{~L}^{-1}$ respectively. Thus, revealing the selectivity mode of action of anthocyanin i.e. toxic towards malignant cells and safe against fibroblast cells.

\section{Morphological studies}

In this part of the study, morphological anomaly if any with anthocyanin treatments was analyzed. No visible morphological changes were noticed for L929 cells with anthocyanin treatments. In fact, HT29, MG63 and HeLa cell lines (Figure 3), showed an increased number of rounded cells and growth inhibition when compared with the untreated control cells. This data further substantiates the MTT results.

Shahneh et al. ${ }^{8}$ reported varied in vitro cytotoxic activity by MTT assay of four herbals used in persian traditional medicine on six cancer cell lines such as non-Hodgkin's B-cell lymphoma, human leukemic monocyte lymphoma, human acute myelocytic leukemia, human breast carcinoma, human Prostate Cancer and mouse fibrosarcoma cell lines and one normal cell line; Human Umbilical Vein Endothelial Cells. Masuda et al. ${ }^{9}$ screened medicinal and edible plants in Okinawa, Japan. Cytotoxic 
activity of ethanol extracts from 36 species was evaluated against K562 human leukemia cells. Rhodea japonica and Hypericum chinense were cytotoxic at a concentration of $10 \mathrm{mg} \mathrm{ml}^{-1}$. The main cytotoxic constituent of Rhodea japonica was isolated and identified as rhodexin A.

Nalbantsoy et al. ${ }^{10}$ analyzed antimicrobial and cytotoxic activities of Zingiber officinalis extracts. The results of the morphological observation and MTT assay revealed that the cytotoxic activity was dose dependent. $\mathrm{IC}_{50}$ values versus L929 and HeLa cells were found to be $87.28 \mu \mathrm{g} \mathrm{ml}^{-1}$ and $74.32 \mu \mathrm{g} \mathrm{ml}^{-1}$, respectively, for the chloroform extract, while the ethanol extract showed $\mathrm{IC}_{50}$ values at $101 \mu \mathrm{g} \mathrm{ml}^{-1}$ and $33.78 \mu \mathrm{g} \mathrm{ml}^{-1}$, respectively.

Weisburg et al. ${ }^{11}$ compared the in vitro cytotoxicity of epigallocatechin gallate and tea extracts against cancerous and normal cells from the human oral cavity. Negahdari et al. ${ }^{12}$ compared wound healing activity of extracts and herbal formulations of Aloe vera, henna, Adiantum capillusveneris on mouse dermal fibroblast cells. All the results substantiate that phytochemicals from plants showed selective toxicity against cells in a varied manner as revealed by the anthocyanin of the present study.

\section{CONCLUSION}

In the present study, significant antiproliferative activity was found, which varied among the Begonia species, but the values were acceptable comparing to the international standards. Further work is required to isolate and characterize the individual bioactive fraction of anthocyanin and to evaluate its potentiality.

\section{CONFLICT OF INTEREST}

The authors declare that there are no conflicts of interest pertaining to this work.

\section{ABBREVIATION USED}

2,4-D: 2,4-Dichlorophenoxyacetic acid; BAP: Benzyl Amino Purine; Kn: Kinetin; NAA: Naphtalic Acetic Acid

\section{ACKNOWLEDGEMENT}

The authors are indebted to Kerala State Council for Science Technology and Environment, Govt. of Kerala for funding the major project.

\section{REFERENCES}

1. Schwartsmann G, Ratain MJ, Cragg GM, Wang GE, Saijo N, Parkinson DR Anticancer drug discovery and development throughout the world. J Clin. Oncol. 2002;20(18 S):47S-59S.

2. Andersen M, Jordheim M. Anthocyanins-food applications. Presented at Proc. 5th Int. Congr. Pigments Foods: For Quality and Health. Helsinki, Finl. 2008;14-6.

3. Hou DX. Potential mechanisms of cancer chemoprevention by anthocyanins. Curr Mol Med. 2003;3(2):149-59.

4. Sutharut J, Sudarat J. Total anthocyanin content and antioxidant activity of germinated colored rice. Inter. Food Res. J. 2012;19(1):215-21.

5. Talarico LB, Mazzucco MB, Vatansever S, Caro AC, Fascio ML, Accoroso NB, et al. Antiviral activity of $\mathrm{N}$-allyl acridone against dengue virus. 2015:22(1):29 10.1186/s12929-015-0134-2.

6. Saniewski M, Horbowicz M, Puchalski J. Induction of anthocyanins accumulation by methyl jasmonate in shoots of Crassula multicava Lam. Acta agrobot. 2006;59(2):43-50

7. Cetin ES, Baydar NG. Elicitor applications to cell suspension culture for production of phenolic compounds in grapevine Tarım Bilimleri Dergisi. JAS 2016;22(1):42-53

8. Shahneh FZ, Baradaran B, Orangi M, Zamani F. In vitro cytotoxic activity of four plants used in persian traditional medicine. Adv. Pharm. Bull. 2013;3(2):453-5.

9. Masuda T, Oyama Y, Yamamoto N, Umebayashi C, Nakao H, Toi Y, et al. Cytotoxic screening of medicinal and edible plants in Okinawa, Japan, and identification of the main toxic constituent of Rhodea japonica (Omoto). Biosci. Biotechnol. Biochem. 2003:67(6):1401-4.

10. Nalbantsoy A, Tamis DA, Akgün IH, Yalçin TO, Gürhan ID, Karaboz I. Antimicrobial and cytotoxic activities of Zingiber officinalis extracts FABAD. J. Pharm. Sci. 2010;33:76-85.

11. Weisburg JH, Weissman $D B$, Sedaghat $T$, Babich $H$. In vitro cytotoxicity of epigallocatechin gallate and tea extracts to cancerous and normal cells from the human oral cavity. BCPT. 2004;95(4):191-200.

12. Negahdari S, Galehdari H, Kesmati M, Rezaie A, Shariati G. Wound healing activity of extracts and formulations of Aloe vera, henna, Adiantum capillus-veneris, and myrrh on mouse dermal fibroblast cells. Int. J Prev. Med. 2017;8:18-27.
GRAPHICAL ABSTRACT

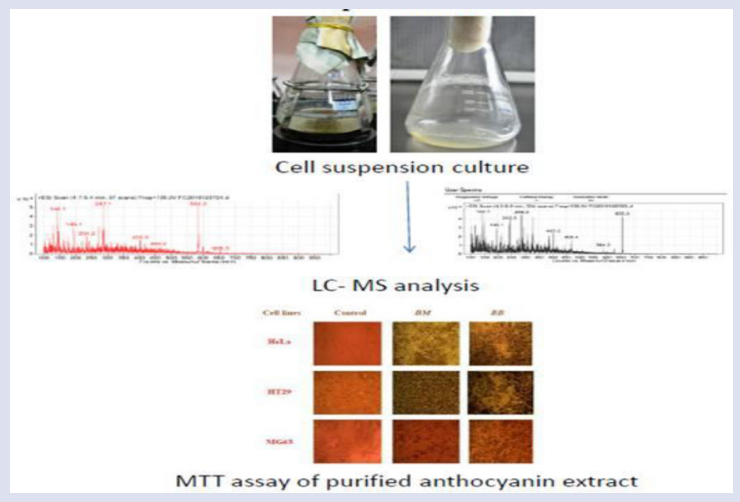

\section{SUMMARY}

- The present investigation reveals an optimal protocol for the synthesis of anthocyanin in Begonia malabarica and B. rexcultorum 'Baby rainbow'.

- Anthocyanin content recorded in cell suspension culture was significantly higher compared with in vivo plants grown in fields.

- The anthocyanin showed significant antiproliferative activity, which varied among the Begonia species.

\section{ABOUT AUTHORS}

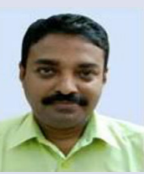

Dr. Murugan K: Is the Deputy Director of Collegiate Education (full additional charge), Govt. of Kerala, India. His research areas include the Biochemistry of natural dyes, Stress physiology and Molecular defence mechanisms.

Cite this article: Madanakumar AJ, Kumaraswamy M. Purified Anthocyanin, its Elicitation from Cell Cultures of Begonia malabarica and Begonia rex - cultorum 'Baby Rainbow'and it's In vitro Cytotoxicity Analysis by MTT Assay. Pharmacog J. 2018;10(3):553-8. 